Majeed, A., Jiang, P., Ahmad, M., Khan, M. A., \& Olah, J. (2021). The Impact of Foreign Direct Investment on Financial Development: New Evidence from Panel Cointegration and Causality Analysis. Journal of Competitiveness, 13(1), 95-112. https://doi.org/10.7441/joc.2021.01.06

\title{
The Impact of Foreign Direct Investment on Financial Development: New Evidence from Panel Cointegration and Causality Analysis
}

\section{- Abdul Majeed, Ping Jiang, Mahmood Ahmad, Muhammad Asif Khan, Judit Olah}

\begin{abstract}
Foreign direct investment (FDI) is seen as a prerequisite for gaining and maintaining competitiveness. Simultaneously, the relationship between FDI and financial development (FD) has important implications for the researched economy and its competitiveness. This domain has not been sufficiently investigated, with diverse and contradictory findings evident in the literature. Therefore, this study investigates the effect of FDI on FD for the selected 102 Belt and Road Initiative countries on four continents: Asia, Europe, Africa, and Latin America. Based on data from 1990 to 2017, a set of quantitative techniques, including feasible generalized least squares, and augmented mean group techniques, were used in this study. Our findings indicate that FDI, trade openness, government consumption, and inflation have a statistically significant relationship with FD. FDI, trade openness, and government consumption increased FD in Asia, Europe, and Latin America but decreased in Africa. Inflation shows a negative influence on FD in all continents. Furthermore, the Dumitrescu-Harlin panel causality test confirms a two-way causality relationship among FDI, trade openness, and FD in Asia and Europe. In contrast, a unidirectional relationship exists between FDI and FD in Latin America. The income-wise results reveal that low- and middle-income countries attract more FDI than high-income countries due to high factor costs. These empirical results provide new insights for policymakers, presenting several policy implications for FD competitiveness in the reference regions.
\end{abstract}

Keywords: foreign direct investment, financial development, panel data, belt and road initiative JEL Classification: B22, F21, G20

Received: August, 2020

1st Revision: January, 2021

Accepted: January, 2021

\section{INTRODUCTION}

Over the past few decades, a drastic increase has been observed in foreign direct investment (FDI) worldwide, which reached $\$ 1.35$ trillion in 2018. In the Belt and Road Initiative (BRI) countries, FDI inward flows increased from $\$ 30.10$ billion to $\$ 43.38$ from 1990 to 2017 (World Bank, 2020). FDI inflows are accepted as a source of competitiveness through knowledge, know-how, and 
technology transfer (Bayar et al., 2020). The BRI has undertaken a great initiative to enhance FDI in the global market, which has brought a large amount of global commerce, international lending, and cross-border investment business. Several studies have highlighted the positive effects of these investments on recipient economies (Iamsiraroj, 2016; Saidi, 2018), including a high level of stability, significant financial resource enhancement, tangible productivity effects, and access to overseas markets (Tsagkanos et al., 2019). Peres et al. (2018) has argued that before the global financial crisis of 2008, developed countries received more FDI flows compared with developing countries; however, after 2008, the situation changed. Global FDI flows from BRI to developing nations increased by 35\% after the 2008 financial crisis. Therefore, FDI became more complicated, as many developing countries have grown faster than rich countries. Hence, the origin/destination of FDI inflows and outflows changed geographically (Buchanan et al., 2012).

Recent research considers the BRI countries to be an appropriate study sample in terms of the diversity and vastness of the regions. More than $\$ 10$ billion has been injected into the Silk Road Fund into a handful policy and development banks to push ahead with significant investments in Asia, Africa, and Europe across multiple sectors (Frankopan, 2017). This phenomenon gives Western globalization an alternative growth model, although only a single country governs it. The question of whether this phenomenon would lead to more positive and equal globalization requires further investigation (Enderwick, 2018). Financial development (FD) is also important for developing countries because it has been shown in the literature that FD boosts economic growth (Sobiech, 2019).

Moreover, an excellent financial system can help transform savings into investment and optimize resource allocation irrespective of space and time and spread risk for investors. Recently, FDI has attracted increased attention from policymakers and academic researchers due to its increasing volume. Several studies have been devoted to gauging its influence on different dimensions, such as climate change (Zheng \& Sheng, 2017), income inequality (Kaulihowa \& Adjasi, 2018), firm performance (Borin \& Mancini, 2016), and, most importantly, economic growth (Aziz \& Makkawi, 2012; Bayar \& Gavriletea, 2018). Nevertheless, only a limited number of studies have been devoted to the effect of FDI on FD (Henri et al., 2019; Islam et al., 2021; Khan et al., 2020). Moreover, the important panel of BRI has been ignored. Therefore, the objective of the present study is to address these shortcomings empirically by exploring the dynamic relationship between FDI and FD in the context of BRI countries.

This study contributes to the existing literature in the following manner. Firstly, this study expands the determinants of FD in demonstrating how FDI affects FD. Secondly, in contrast to previous literature Hajilee \& Nasser (2015), the present study uses a relatively new measure of FD proposed by the International Monetary Fund (IMF) (Svirydzenka, 2016). This index encompasses financial markets and institutions in terms of access, depth, and efficiency. Khan et al. (2019a) and Khan et al. (2020) have recently contended that the FD index established by the IMF fully encompasses diverse financial systems that are not covered by traditional proxies in the literature due to several limitations. Thirdly, this study uses second-generation long-run panel co-integration and the short-run causal relationship using Dumitrescu-Hurlin (D-H) 
causality analysis in the presence of cross-sectional dependence (CSD) and heterogeneity. Finally, in terms of the extensive and diverse panel of BRI countries, this study offers important policy recommendations for member countries across regions and income levels that vary enormously in finances and advancement.

The rest of the paper is structured as follows. Section 2 reviews the theoretical background. Section 3 presents the research objective, methodology, and data. Section 4 discusses the study findings. Section 5 concludes the study results and draws attention to several important policy implications.

\section{THEORETICAL BACKGROUND}

In recent decades, FD has gained considerable attention from researchers, academicians, economists, and policymakers (Durusu-Ciftci et al., 2017). Many researchers have viewed FDI as a boon to an economy due to the technological diffusion it causes (Carkovic \& Levine, 2005; Iamsiraroj, 2016). FDI represents an intermediary force in financial systems due to their absorptive capacity (Yeboua, 2019). FDI draws capital to a host country and brings advanced technology and management experience, thereby further promoting technological progress and economic growth. In addition, investments from multinational companies generally create jobs for the residents of the host country. Nevertheless, existing studies have been less concerned with the influence of FDI on host country financial systems or the subsequent development of their financial sectors. Most studies on the topic have emphasized that a host country requires a sufficiently mature financial market for FDI to comprehensively promote economic growth (Alfaro et al., 2010).

Only a few studies have addressed the effect of FDI on FD, focusing on developing or emerging countries. Soumaré et al. (2015) empirically investigated the causal link between FDI and FD measures for a group of 29 developing countries during 1994-2006. The researchers found bidirectional causality between FDI and stock market development indicators. An adequately established monetary system facilitates the efficient distribution of economic resources and increases the absorption ability of an economy regarding FDI inflows. Saidi (2018) empirically investigated the link among FDI, FD, and the economic growth of low-income (LI) countries using data from 1990-2015. These results showed that FDI starters could deliver momentous advantages to LI states concerning technology acquisition, investment arrivals, job creation, human capital development, improved corporate growth levels. Further, a long-run cointegration and two-way causality were found between FDI and FD in LI countries.

Conversely, Bayar \& Gavriletea (2018) show that FDI inflows do not significantly affect FD in the long and short run. However, unidirectional causality exists from financial sector development to FDI inflow in Central and Eastern European Union countries. Therefore, no impact at all, neither negative nor positive, can be observed theoretically. Henri et al. (2019) explained that the short-run effect of FDI on FD is adverse; nevertheless, it is significant in LI economies and insignificance in upper-middle-income (MI) countries. LI countries indicate that FDI improved long-run FD regardless of the income in African states from 1990 to 2016. Hanif \& Shariff (2016) determined that no short-run causal association concerning FDI and FD exists, 
as neither variable causes the other in ASEAN countries. Therefore, these economies should strive to enhance the efficiency of the domestic monetary system to make it more accessible for stakeholders to enter and participate in these respective states. In summary, most studies have considered FDI to be a channel to FD and then to the economic growth, with a few studies examining the direct effect of FDI on FD. Furthermore, only limited research has been conducted on individual economies or groups of similar economies. In contrast, the present study used a heterogeneous panel of BRI economies in considering the direct effect of FDI to enhance FD.

\section{RESEARCH OBJECTIVE, METHODOLOGY, AND DATA}

\subsection{Conceptual Framework and Model Description}

The related literature does not provide a consistent theoretical framework that explains a direct link between FDI and FD. However, a theoretical causal relationship between FDI and FD has been demonstrated in three ways. Firstly, Desai et al. (2006) argued that the expansion of FDI inflows increases the overall sum of money accessible for the domestic economy and facilitates financial intermediation via money markets. The banking industry can promote businesses with foreign investors. Secondly, a reasonably well-functioning monetary market can bring international stakeholders who always see such financial market as the symbol of a stable economy, transparency by government authorities, and a business-friendly atmosphere. The well-developed share market increases the investment capital accessible to registered companies and can ultimately cut capital expenditure, making a country appealing for FDI (Desai et al., 2006). Thirdly, Porta et al. (1998) and Kholdy \& Sohrabian (2008) utilized a political and economic model to argue that FDI reduces the relative influence of elite decisions in the host country, which can force the political elite to implement economic friendly regulatory reforms that facilitate the growth of the financial sector.

The direct connection between FDI and FD is still not adequately evaluated empirically, especially in BRI economies. Therefore, the objective of current study is to inspect the link between FDI and FD in BRI countries. The previous literature has shown that FDI is a significant cause of investment flow and an essential technical and manufacturing advancement source. Therefore, the present study used FDI as the main explanatory variable. Earlier related studies also suggest that other variables (e.g., trade openness, government consumption, inflation, and population growth) can also influence FD (Khan et al., 2019b; Khan et al., 2020). This study introduces essential variables that affect FD into the empirical model for realistic and robust estimation. Therefore, trade openness is linked to the expansion of the financial market. Conceivably, trade flows of a country are also significant drivers in enhancing FD (Aibai et al., 2019). The level of government consumption in a country influences FD levels (Kutan et al., 2017).

Given that the market value variations change people saving actions, inflation simultaneously affects FD (Aibai et al., 2019; Kaidi et al., 2019; Khan et al., 2019a). As socioeconomic scales of a nation population growth influence its social burden on its economy. Population growth is also closely associated with FD (Kutan et al., 2017). Based on a detailed analysis of empirical literature and theoretical foundations, this research postulates the following hypothesis. 
H0: FDI does not pose a significant positive effect on FD in the long run.

H1: FDI poses a significant positive effect on FD in the long run.

The connection among these variables is expressed in Eq. (1).

$F D_{i, t}=\beta_{0}+\beta_{1} F D I_{i, t}+\beta_{2} T O_{i, t}+\beta_{3} G C_{i, t}+\beta_{4} I N F_{i, t}+\beta_{5} P G_{i, t}+\varepsilon_{i, t}$

where FD demonstrates that the FD index, FDI displays the FDI net inflows as a percentage of GDP, TO shows trade openness, the ratio of total imports and exports divided by country GDP, GC shows the general government final consumption expenditure divided by GDP, INF shows the inflation GDP deflator yearly ratio, PG shows the population annual growth rate, t denotes the time (1990-2017) and subscript $i$ indicates the cross-sections (102 BRI countries). List of the sample BRI countries is available on request. The FD index data is collected from the IMF, and the rest of the variables are collected from the World Development Indicators (WDI), which are the most acceptable and reliable data sources currently available for empirical finding. The selection of the study duration and the countries are based on the availability of the relevant data.

\subsection{Econometric Techniques}

When formulating the econometric methodology, CSD and homogeneity are important in econometric test selections. The methodology used is briefly discussed below.

\subsection{Cross-Sectional Dependence (CSD) and Slope Homogeneity Tests}

The BRI countries are interconnected through several cultural, economic, and social networks since ignorance of CSD may give misleading and biased estimates. The study used the Pesaran (2004) CSD and Pesaran Scaled LM test, which assumes that cross-sections are independent, tested against the alternative hypothesis of CSD. The test equation of CSD is as follows:

$C D=\sqrt{\frac{2 T}{N(N-1)}}\left(\sum_{i=1}^{N-1} \sum_{j=i+1}^{N} \hat{\rho}_{i j}\right)$

Where $\hat{\rho}_{i j}$ indicates the pairwise correlation. Where $\mathrm{N}$ specifies the sample, T represents time.

Subsequently, This study applied the slope homogeneity test of Pesaran and Yamagata (2008), to unveil the slope heterogeneity between the cross-sections. The null and alternative hypotheses of slope homogeneity analyses are as follows. Null hypothesis: Ho: $\beta \mathrm{i}=\beta$ for all $\mathrm{i}$ (cross-section); alternative hypothesis: $\mathrm{H1}: \beta \mathrm{i} \neq \beta \mathrm{j}$ for $\mathrm{i} \neq \mathrm{j}$.

\subsection{Panel Unit Root Tests}

Based on CSD, the right integration order may be determined under non-parametric and parametric settings. Banerjee et al. (2001) investigated the risks of over-rejecting the null hypothesis in the existence of CSD. To come across CSD, Pesaran (2007) suggested a new test because the traditional tests were not acceptable. Therefore, CIPS and CADF tests for unit root Pesaran (2007), for second-generation, were applied for unit-root scrutiny. These tests overcome CSD and heterogeneity. 


\subsection{Panel Cointegration Analysis}

A cointegration-based formation derives the probability of at least one unidirectional Granger causal relationship. Observations on order $(1,1)$ of two variables are cointegrated if they are independently non-stationary; however, the direct connection showed stationary. In case of CSD, Westerlund (2007) cointegration analysis, named as a second-generation test for co-integration, is suitable to use. The CSD problem is managed using bootstrapped adaptation. To verify cointegration, the Westerlund test followed the error corrections model. This test displayed four statistics: Pt, Pa (panel statistics), and Gt and Ga (group statistics). To reject the null hypothesis of $\mathrm{Ga}$ and $\mathrm{Gt}$ implies that at least one of the cross-sections must have co-integration. In the same manner, the null hypothesis rejection of $\mathrm{Pa}$ and $\mathrm{Pt}$ shows that panel has co-integration. Because of CSD, reliable p-value was determined by bootstrapping 400 times.

\subsection{Panel Causality Analysis}

The causality among the variables identified after co-integration is confirmed to analyze the directional flow causal relationships between variables. As a result of CSD, the Dumitrescu \& Hurlin (2012) D-H method is used, constructed on Granger (1969) and single Wald statistic average of non-causality (sample) countries. The null hypothesis of D-H causality is assumed as: no causal link was observed between variables against the alternative hypothesis, the present of the causal relationship between variables. The model can be expressed as:

$z_{i, t}=\alpha_{i}+\sum_{j=1}^{p} \beta_{i}^{j} z_{i, t-j}+\sum_{j=1}^{p} \gamma_{i}^{j} T_{i, t-j}$

$j$ denotes the lag length $\beta(j)$ denotes the autoregressive parameters.

\subsection{Feasible Generalized Least Squares (FGLS)}

FGLS estimator was used when heteroscedasticity, serial correlation, and CSD exist in the panel data, specified by (Reed \& Ye, 2011). The mathematical equation of the variables and coefficients of FGLS and ordinary least squares (OLS) estimations is;

$\hat{B}=\left(X^{\prime} \hat{\Omega}^{-1} X\right)^{-1} X^{\prime} \hat{\Omega}^{-1} y$

$\operatorname{Var}(\hat{B})=\left(X^{\prime} \hat{\Omega}^{-1} X\right)^{-1}$

where $\mathbf{\Omega}$ contains the serial correlation, heteroscedasticity, and CSD assumptions. The FGLS analysis is essential when the total number of cross-sections is less than or equivalent to the total number of years (Reed \& Ye, 2011). This precondition $(\mathrm{N} \leq \mathrm{T})$ is satisfied in the entire panel of this study. Further, the robustness check for this analysis is confirmed using the Augmented Mean Group (AMG) method of (Eberhardt, 2012).

\section{RESULTS AND DISCUSSION}

\subsection{CSD, Slope Homogeneity and Panel Unit Root Results}

Table 1 shows CSD across four panels of the BRI countries. In the panel data, the existence 
of CSD suggests using the second-generation CIPS and CADF panel unit root tests, secondgeneration techniques for co-integration, D-H causality with FGLS test for regression results. AMG regression was also suitable for long-run studies in the existence of CSD (Reed \& Ye, 2011). The slope homogeneity test infers that the homogeneity hypothesis is refused and supports slope heterogeneity within panels.

Tab.1 - Cross-sectional dependence (CSD) and slope homogeneity test results. Source: own research

\begin{tabular}{|l|l|l|l|l|}
\hline & Asia & Europe & Africa & Latin America \\
\hline & Test-stat. & Test-stat. & Test-stat. & Test-stat. \\
\hline CSD test & & & & \\
\hline Psarian CSD & $26.942^{* * *}$ & $19.409^{* * *}$ & $32.022^{* * *}$ & $25.523^{* * *}$ \\
\hline Bias- correlated scales LM & $76.864 * * *$ & $73.377^{* * *}$ & $85.339 * * *$ & $55.015^{* * *}$ \\
\hline Pesaran scaled LM & $77.383^{* * *}$ & $73.895^{* * *}$ & $85.857 * * *$ & $55.348^{* * *}$ \\
\hline Slope homogeneity test & & & & \\
\hline Pesaran, Yamagata (2008) & $18.870^{* * *}$ & $19.095^{* * *}$ & $15.142^{* * *}$ & $17.367^{* * *}$ \\
\hline *** Significance 1 \%, ** Significance $5 \%, *$ Significance $10 \%$ & \\
\hline
\end{tabular}

For brevity, and conciseness panel unit root table is not reported, however, it is available on request. It discloses panel unit root test results under dual conditions (a) at level (b) at first difference. However, CIPS and CADF tests discovered diverse findings at level; at the first difference, all variables are stationary. The unit root test lag length was selected through Schwarz automatic selection criteria. Pedroni (2004) co-integration test is appropriate when the variables are stationary at the first difference. However, in the existence of CSD, the second-generation test of Westerlund (2007) panel co-integration test is more appropriate to use.

\subsection{Panel Cointegration Analysis}

Table 2 shows that all four panels were cointegrated. The null hypothesis was rejected as a result of significant test statistics. As a result, the long-run relationship between the specified variables was established. The recognition of co-integration infers the probability for at least one unidirectional Granger causal connection.

Tab. 2 - Westerlund panel cointegration test results. Source: own research

\begin{tabular}{|l|l|l|l|l|l|}
\hline \multirow{2}{*}{ Region } & Statistic & Value & Z-value & P-value & $\begin{array}{l}\text { Robust } \\
\text { P-value }\end{array}$ \\
\hline \multirow{2}{*}{ Asia } & $\mathrm{Gt}$ & $-2.914 * * *$ & -3.674 & 0.000 & 0.000 \\
\cline { 2 - 6 } & $\mathrm{Ga}$ & $-15.799 * * *$ & -3.103 & 0.001 & 0.000 \\
\cline { 2 - 6 } & $\mathrm{Pt}$ & $-13.987 * * *$ & -3.270 & 0.001 & 0.000 \\
\cline { 2 - 6 } & $\mathrm{Pa}$ & $-12.709 * * *$ & -3.327 & 0.000 & 0.000 \\
\hline \multirow{2}{*}{ Europe } & $\mathrm{Gt}$ & -2.572 & -1.425 & 0.077 & 1.000 \\
\cline { 2 - 6 } & $\mathrm{Ga}$ & $-12.978^{* * *}$ & -0.859 & 0.195 & 0.000 \\
\hline
\end{tabular}




\begin{tabular}{|c|c|c|c|c|c|}
\hline \multirow[t]{2}{*}{ Europe } & $\mathrm{Pt}$ & $-12.251 * * *$ & -1.609 & 0.054 & 0.000 \\
\hline & $\mathrm{Pa}$ & $-11.239 * * *$ & -2.024 & 0.022 & 0.000 \\
\hline \multirow[t]{4}{*}{ Africa } & Gt & -2.902 & -3.597 & 0.000 & 0.200 \\
\hline & $\mathrm{Ga}$ & -15.949 & -3.223 & 0.001 & 0.400 \\
\hline & $\mathrm{Pt}$ & $-15.099 * * *$ & -4.565 & 0.000 & 0.000 \\
\hline & $\mathrm{Pa}$ & $-15.154 * * *$ & -5.493 & 0.000 & 0.000 \\
\hline \multirow{4}{*}{$\begin{array}{l}\text { Latin } \\
\text { America }\end{array}$} & Gt & $-2.816^{* * *}$ & -2.431 & 0.008 & 0.000 \\
\hline & $\mathrm{Ga}$ & $-23.751 * * *$ & -7.560 & 0.000 & 0.000 \\
\hline & $\mathrm{Pt}$ & $-11.122 * * *$ & -2.514 & 0.006 & 0.000 \\
\hline & $\mathrm{Pa}$ & $-20.911 * * *$ & -8.493 & 0.000 & 0.000 \\
\hline
\end{tabular}

\subsection{Panel Causality Results}

Table 3 shows the D-H causality results. FDI and FD show the feedback relationship, which suggests that FDI granger causes FD; in response, FD also granger causes FDI in Asia and Europe (Bayar \& Gavriletea 2018; Bhattacharya et al., 2018). A similar relationship exists between trade openness and FD in these two regions (Fan et al., 2018). However, our results indicate a unidirectional relationship from FDI to FD in Latin America, suggesting that FDI granger causes FD, but not the reverse. Therefore, FDI has a vital role in enhancing FD in the short run, whereas FD has no significant influence on attracting FDI inflows. These findings are consistent with the relevant literature (Sahin \& Ege, 2015). FDI and FD had no causal relationship in Africa (Henri et al., 2019).

Tab. 3 - Panel D-H causality test results. Source: own research

\begin{tabular}{|c|c|c|c|c|c|c|}
\hline Variables & FD & FDI & TO & GC & INF & PG \\
\hline \multicolumn{7}{|l|}{ Asia } \\
\hline FD & & $\begin{array}{l}5.538^{* * *} \\
(0.004)\end{array}$ & $\begin{array}{l}3.129 * * \\
(0.047)\end{array}$ & $\begin{array}{l}2.640 \\
(0.354)\end{array}$ & $\begin{array}{l}3.245^{* *} \\
(0.025)\end{array}$ & $\begin{array}{l}5.298 \\
(3.011)\end{array}$ \\
\hline FDI & $\begin{array}{l}3.042^{* *} \\
(0.043)\end{array}$ & & $\begin{array}{l}2.761 \\
(0.235)\end{array}$ & $\begin{array}{l}3.085^{* *} \\
(0.059)\end{array}$ & $\begin{array}{l}3.768^{* * *} \\
(0.000)\end{array}$ & $\begin{array}{l}4.671 \\
(1.007)\end{array}$ \\
\hline TO & $\begin{array}{l}3.222 * * \\
(0.029)\end{array}$ & $\begin{array}{l}3.938^{* * *} \\
(0.000)\end{array}$ & & $\begin{array}{l}3.620^{* * *} \\
(0.002)\end{array}$ & $\begin{array}{l}9.911 * * * \\
(0.000)\end{array}$ & $\begin{array}{l}4.896 \\
(7.009)\end{array}$ \\
\hline GC & $\begin{array}{l}2.651 \\
(0.341)\end{array}$ & $\begin{array}{l}2.333 \\
(0.790)\end{array}$ & $\begin{array}{l}3.707 * * * \\
(0.001)\end{array}$ & & $\begin{array}{l}8.885^{* * *} \\
(0.000)\end{array}$ & $\begin{array}{l}7.862^{* * *} \\
(0.000)\end{array}$ \\
\hline INF & $\begin{array}{l}2.884 \\
(0.146)\end{array}$ & $\begin{array}{l}3.290 * * \\
(0.020)\end{array}$ & $\begin{array}{l}2.714 \\
(0.277)\end{array}$ & $\begin{array}{l}6.543^{* * *} \\
(0.000)\end{array}$ & & $\begin{array}{l}8.637^{* * *} \\
(0.000)\end{array}$ \\
\hline PG & $\begin{array}{l}2.625 \\
(0.371)\end{array}$ & $\begin{array}{l}2.378 \\
(0.717)\end{array}$ & $\begin{array}{l}2.735 \\
(0.258)\end{array}$ & $\begin{array}{l}6.965^{* * *} \\
(0.000)\end{array}$ & $\begin{array}{l}4.644 \\
(2.007)\end{array}$ & \\
\hline
\end{tabular}




\begin{tabular}{|c|c|c|c|c|c|c|}
\hline \multicolumn{7}{|c|}{ Europe } \\
\hline FD & & $\begin{array}{l}5.033 * * * \\
(0.006)\end{array}$ & $\begin{array}{l}2.130 * * * \\
(0.000)\end{array}$ & $\begin{array}{l}1.654^{*} \\
(0.071)\end{array}$ & $\begin{array}{l}1.336 \\
(0.431)\end{array}$ & $\begin{array}{l}4.902^{* * *} \\
(0.000)\end{array}$ \\
\hline FDI & $\begin{array}{l}2.026^{* * *} \\
(0.002)\end{array}$ & & $\begin{array}{l}0.841 \\
(0.425)\end{array}$ & $\begin{array}{l}2.370 \\
(4.005)\end{array}$ & $\begin{array}{l}1.193 \\
(0.742)\end{array}$ & $\begin{array}{l}2.764 \\
(9.028)\end{array}$ \\
\hline TO & $\begin{array}{l}2.134 * * * \\
(0.000)\end{array}$ & $\begin{array}{l}1.440 \\
(0.263)\end{array}$ & & $\begin{array}{l}2.413 \\
(2.015)\end{array}$ & $\begin{array}{l}3.004 \\
(9.010)\end{array}$ & $\begin{array}{l}2.583 \\
(2.106)\end{array}$ \\
\hline GC & $\begin{array}{l}2.282^{* * *} \\
(0.000)\end{array}$ & $\begin{array}{l}1.305 \\
(0.492)\end{array}$ & $\begin{array}{l}4.244 * * * \\
(0.000)\end{array}$ & & $\begin{array}{l}5.672 * * * \\
(0.000)\end{array}$ & $\begin{array}{l}3.375 \\
(3.013)\end{array}$ \\
\hline INF & $\begin{array}{l}3.192 \\
(2.011)\end{array}$ & $\begin{array}{l}1.592 \\
(0.108)\end{array}$ & $\begin{array}{l}2.676 \\
(4.071)\end{array}$ & $\begin{array}{l}3.503 \\
(1.014)\end{array}$ & & $\begin{array}{l}3.629 \\
(4.016)\end{array}$ \\
\hline PG & $\begin{array}{l}1.033 \\
(0.854)\end{array}$ & $\begin{array}{l}1.387 \\
(0.343)\end{array}$ & $\begin{array}{l}1.246 \\
(0.619)\end{array}$ & $\begin{array}{l}2.173^{* * *} \\
(0.000)\end{array}$ & $\begin{array}{l}1.630^{*} \\
(0.084)\end{array}$ & \\
\hline \multicolumn{7}{|c|}{ Africa } \\
\hline FD & & $\begin{array}{l}1.316 \\
(0.470)\end{array}$ & $\begin{array}{l}4.268 \\
(0.140)\end{array}$ & $\begin{array}{l}4.992^{* * *} \\
(0.007)\end{array}$ & $\begin{array}{l}4.419 * \\
(0.085)\end{array}$ & $\begin{array}{l}7.606 \\
(3.001)\end{array}$ \\
\hline FDI & $\begin{array}{l}2.609 \\
(0.311)\end{array}$ & & $\begin{array}{l}4.351 \\
(0.107)\end{array}$ & $\begin{array}{l}4.692 * * \\
(0.029)\end{array}$ & $\begin{array}{l}5.736 * * * \\
(0.000)\end{array}$ & $\begin{array}{l}10.980 \text { *** } \\
(0.000)\end{array}$ \\
\hline TO & $\begin{array}{l}4.025 \\
(0.283)\end{array}$ & $\begin{array}{l}3.962 \\
(0.332)\end{array}$ & & $\begin{array}{l}5.759 \\
(8.001)\end{array}$ & $\begin{array}{l}4.867^{* *} \\
(0.013)\end{array}$ & $\begin{array}{l}7.667 \\
(1.020)\end{array}$ \\
\hline GC & $\begin{array}{l}4.234 \\
(0.156) \\
\end{array}$ & $\begin{array}{l}4.391 * \\
(0.093) \\
\end{array}$ & $\begin{array}{l}5.062^{* * *} \\
(0.005) \\
\end{array}$ & & $\begin{array}{l}3.809 \\
(0.473) \\
\end{array}$ & $\begin{array}{l}6.922 \\
(5.001) \\
\end{array}$ \\
\hline INF & $\begin{array}{l}5.903 \\
(3.001) \\
\end{array}$ & $\begin{array}{l}4.766^{* *} \\
(0.021)\end{array}$ & $\begin{array}{l}2.469 \\
(0.135)\end{array}$ & $\begin{array}{l}3.162 \\
(0.726) \\
\end{array}$ & & $\begin{array}{l}5.828 \\
(5.001) \\
\end{array}$ \\
\hline PG & $\begin{array}{l}4.303 \\
(0.125)\end{array}$ & $\begin{array}{l}4.921 * * \\
(0.010)\end{array}$ & $\begin{array}{l}7.043 \\
(1.001)\end{array}$ & $\begin{array}{l}6.533 \\
(2.001)\end{array}$ & $\begin{array}{l}12.237 * * * \\
(0.000)\end{array}$ & \\
\hline \multicolumn{7}{|c|}{ L. America } \\
\hline FD & & $\begin{array}{l}2.604 \\
(0.396)\end{array}$ & $\begin{array}{l}3.835 \\
(0.542\end{array}$ & $\begin{array}{l}4.824 * \\
(0.055)\end{array}$ & $\begin{array}{l}3.412 \\
(0.960)\end{array}$ & $\begin{array}{l}9.670 * * * \\
(0.000)\end{array}$ \\
\hline FDI & $\begin{array}{l}4.703 * * \\
(0.028)\end{array}$ & & $\begin{array}{l}2.325 \\
(0.165)\end{array}$ & $\begin{array}{l}6.511 \\
(3.015)\end{array}$ & $\begin{array}{l}3.661 \\
(0.704)\end{array}$ & $\begin{array}{l}4.103 \\
(0.336)\end{array}$ \\
\hline TO & $\begin{array}{l}3.288 \\
(0.909)\end{array}$ & $\begin{array}{l}4.152 \\
(0.304)\end{array}$ & & $\begin{array}{l}5.809 * * * \\
(0.001)\end{array}$ & $\begin{array}{l}6.217 * * * \\
(0.000)\end{array}$ & $\begin{array}{l}9.010 \\
(9.014)\end{array}$ \\
\hline GC & $\begin{array}{l}7.019 \\
(1.016) \\
\end{array}$ & $\begin{array}{l}4.899 * * \\
(0.043)\end{array}$ & $\begin{array}{l}8.164 \\
(2.010) \\
\end{array}$ & & $\begin{array}{l}5.058^{* *} \\
(0.026)\end{array}$ & $\begin{array}{l}6.261 * * * \\
(0.001)\end{array}$ \\
\hline INF & $\begin{array}{l}7.251 \\
(3.017) \\
\end{array}$ & $\begin{array}{l}3.419 \\
(0.953)\end{array}$ & $\begin{array}{l}4.046 \\
(0.374) \\
\end{array}$ & $\begin{array}{l}6.402 \\
(6.015) \\
\end{array}$ & & $\begin{array}{l}5.049 * * \\
(0.026)\end{array}$ \\
\hline PG & $\begin{array}{l}10.744^{* * *} \\
(0.000)\end{array}$ & $\begin{array}{l}6.199 * * * \\
(0.000)\end{array}$ & $\begin{array}{l}5.261 * * \\
(0.012) \\
\end{array}$ & $\begin{array}{l}6.514 \\
(3.015) \\
\end{array}$ & $\begin{array}{l}5.915^{* * *} \\
(0.000)\end{array}$ & \\
\hline p-valu & rentheses w & **** Signi & ance $1 \%$, & Significanc & $\%$, * Signi & cance $10 \%$ \\
\hline
\end{tabular}




\subsection{Regression Results and Discussion}

The regression results are shown in Table 4 . The FDI coefficient values are positive and significant for Asia (0.314), Europe (0.179), and Latin America (0.457), as indicated by the FGLS regression method. So, FDI has a significant positive impact on FD in the BRI countries. These results show that when foreign companies entered into the BRI countries, they came with important financial investments in FDI, franchises, mergers, and acquisitions with the present companies. In such cases, overseas investments transferred towards BRI economies improve the structures, strengthen the financial markets, and circulate more capital. Indeed, FDI improves countries financial independence and strengthens their access to technology and capital markets by developing financial sector capacity and financial intermediation (Sayllır et al., 2018). Mahmoodi \& Mahmoodi (2016) realized that FDI has become more beneficial in Asian countries than in other developing economies with a conservative and focused strategy. Our research hypothesis is validated as FDI has a significant positive relationship with FD in the BRI countries. However, in Africa, FDI harms FD, having a coefficient value of -0.050, as per FGLS estimation.

A well-developed financial sector is a precondition for the positive impact of FDI. We may infer that the underdevelopment of Africa financial systems does not effectively perform its functions and effectively allocate financial resources. Therefore, African nations must implement initiatives to boost local conditions by increasing absorption capability, thereby closing the technological gap. Besides, government policy also plays a key role in making the most of FDI. African countries can support economic growth by importing cutting-edge technologies to improve local product quality, reduce average production costs, and increase international market share by increasing exports (Saidi, 2018). As a result, our research hypothesis is not validated in the case of African countries. The FGLS regression results confirm a significant positive effect of trade openness on FD in BRI countries. BRI economies have a more regional trade presence, such as the digitalization of trade openness, which produces enormous benefits in production and trade. Therefore, trade openness is beneficial for financial market expansion (Aibai et al., 2019; Kim et al., 2010; Le et al., 2016).

A positive connection exists between government consumption and FD, which indicates that a stable government facilitates financial system advancement. This phenomenon can be attributed to how the growth of a nation's financial system appears to be highly reliant on unpredictable market conduct. That sound government improves the capital assets distribution in local markets (Aibai et al., 2019). Inflation has a significant negative link with FD. Therefore, inflation has been linked with financial instability, increasing inflation harming the financial system's stability and operations. Lastly, population growth has mixed effects on FD (Kaidi et al., 2019). Harm typically occurs when population growth is faster than economic resources, which need to be narrowly distributed across the population. However, this situation will improve the country's savings and boost the FD level (Becker, 2007; Butler \& Cornaggia, 2011). Furthermore, to facilitate financial systems' response to such convergence, critical socioeconomic element stability such as stable population growth is necessary (Katircioğlu \& Zabolotnov, 2019). The AMG regression results show similar effects. 
Tab. 4 - Regression results of FD in BRI countries. Source: own research

\begin{tabular}{|c|c|c|c|c|}
\hline & Asia & Europe & Africa & Latin America \\
\hline \multicolumn{5}{|c|}{ FGLS regression model (long run) } \\
\hline FDI & $0.314 * * *(0.073)$ & $0.179 * * *(0.051)$ & $-0.050(0.040)$ & $0.457 * * *(0.058)$ \\
\hline TO & $0.118^{* * *}(0.006)$ & $0.095^{* * *}(0.009)$ & $0.018^{* * *}(0.007)$ & $0.039 * * *(0.009)$ \\
\hline GC & $0.081 *(0.049)$ & $0.490 * * *(0.113)$ & $0.181 * * *(0.039)$ & $0.107 * *(0.049)$ \\
\hline INF & $-0.025^{* * *}(0.005)$ & $-0.022 * * *(0.003)$ & $0.001(0.002)$ & $-0.016^{* * *}(0.006)$ \\
\hline PG & $0.191(0.194)$ & $5.406^{* * *}(0.565)$ & $-2.925^{* * *}(0.252)$ & $-2.382 * * *(0.329)$ \\
\hline Constant & $22.547 * * *(0.849)$ & $13.430 * * *(2.232)$ & $17.498^{* * *}(1.034)$ & $18.590 * * *((1.052)$ \\
\hline Observations & 784 & 784 & 784 & 504 \\
\hline Number of id & 28 & 28 & 28 & 18 \\
\hline \multicolumn{5}{|c|}{ AMG regression (long run) } \\
\hline FDI & $0.431 *(0.254)$ & $0.587 * * *(0.224)$ & $-0.055(0.063)$ & $0.091 * *(0.039)$ \\
\hline TO & $0.107 *(0.056)$ & $0.039(0.053)$ & $0.121 * *(0.049)$ & $0.014(0.014)$ \\
\hline GC & $0.012(0.360)$ & $-0.046(0.250)$ & $0.935^{* * *}(0.323)$ & $0.174 * *(0.078)$ \\
\hline INF & $-0.114 * *(0.054)$ & $-0.190 *(0.111)$ & $-0.034(0.040)$ & $0.029(0.022)$ \\
\hline PG & $-2.760 *(1.554)$ & $2.336 *(1.193)$ & $-6.078 *(3.625)$ & $-1.509(0.987)$ \\
\hline Constant & $32.062 * * *(7.041)$ & $27.123 * * *(6.601)$ & $9.060(3.789)$ & $11.319 * * *(3.066)$ \\
\hline Observations & 784 & 784 & 784 & 504 \\
\hline Number of id & 28 & 28 & 28 & 18 \\
\hline \multicolumn{5}{|c|}{$\begin{array}{l}\text { Standard error in parentheses with } * * * \text { Significance } 1 \%, * * \text { Significance } 5 \%, * \text { Significance } \\
10 \%\end{array}$} \\
\hline
\end{tabular}

\subsection{Robustness}

Table 5 demonstrates the long-run relationship between FDI and FD in BRI countries, separated by three types of income levels, LI, MI, and high income (HI) groups, to cover the variability of income in the dataset. The results show that FDI has a significant positive effect on LI (0.752), MI (0.629), and HI (0.480) countries. These results provide significant implications, as HI countries have a profound financial system that attracts less FDI as compared with LI and MI countries. This phenomenon can occur due to high factors costs, such as land, labor, and capital in HI countries. International companies searching for new investment locations and investing less in HI countries (Liu et al., 2020). Furthermore, government consumption has a positive connection with FD. Therefore, higher government consumption can positively affect FD when the government invests in productive zones. If countries levy taxes efficiently and effectively, then the higher productive expenditures can result in higher FD. Government consumption is an important policy tool for countries at all income levels.

The results also indicate that inflation has a negative relationship with FD at all income levels. Countries with higher inflation rates are also likely to have a less stable financial sector, resulting in increased lending rates (Fouejieu, 2017). Inflation harms FD in high- and mediuminflationary economies. Furthermore, population growth has a significant positive relationship 
with FD. Conversely, Ozili (2018) has claimed that population growth can put pressure on resource usage. However, this mechanism offers innovation opportunities that are sufficiently effective to revert price increases and increase revenue in time. Hence, the effect of population growth might be mixed. Moreover, international companies are comparatively more productive than local companies in technical ability, resources, and global market accessibility. Therefore, these countries should adopt steps to increase their financial competitiveness to the rest of the world by attracting more foreign investment.

Tab. 5 - Income-wise analysis. Source: own research

\begin{tabular}{|c|c|c|c|}
\hline & Low Income & Middle Income & High Income \\
\hline \multicolumn{4}{|c|}{ FGLS regression model (long run) } \\
\hline FDI & $0.752 * * *(0.130)$ & $0.629^{* * *}(0.121)$ & $0.480^{* * *}(0.112)$ \\
\hline $\mathrm{TO}$ & $0.081 * * *(0.017)$ & $0.227 * * *(0.017)$ & $0.173^{* * *}(0.012)$ \\
\hline GC & $0.658 * * *(0.076)$ & $1.344 * * *(0.065)$ & $0.919 * * *(0.056)$ \\
\hline INF & $-0.020(0.016)$ & $-0.346 * * *(0.069)$ & $-0.017(0.028)$ \\
\hline PG & $2.779 * * *(0.558)$ & $-0.085(0.767)$ & $1.581 * * *(0.481)$ \\
\hline Constant & $16.690 * * *(0.788)$ & $13.542 * * *(0.915)$ & $28.476^{* * *}(6.686)$ \\
\hline Observations & 952 & 980 & 924 \\
\hline Number of ids & 34 & 35 & 33 \\
\hline \multicolumn{4}{|c|}{ AMG regression (long run) } \\
\hline FDI & $0.422 * * *(0.090)$ & $0.337 * * *(0.062)$ & $0.279 * * *(0.069)$ \\
\hline TO & $0.101^{* * *}(0.012)$ & $0.041 * * *(0.009)$ & $0.092^{* * *}(0.018)$ \\
\hline GC & $0.926^{* * *}(0.074)$ & $-0.265^{* * *}(0.090)$ & $-0.389 * * *(0.090)$ \\
\hline INF & $-0.070 * * *(0.025)$ & $-0.012 * *(0.005)$ & $-0.002(0.003)$ \\
\hline PG & $1.778^{* * *}(0.650)$ & $1.421 * * *(0.279)$ & $-0.421(0.293)$ \\
\hline Constant & $14.557 * * *(2.833)$ & $14.834 * * *(3.389)$ & $24.699 * * *(6.957)$ \\
\hline Observations & 952 & 980 & 924 \\
\hline Number of ids & 34 & 35 & 33 \\
\hline \multicolumn{4}{|c|}{$\begin{array}{l}\text { Standard error in parentheses with } * * * \text { Significance } 1 \%, * * \text { Significance } 5 \%, * \text { Significance } \\
10 \%\end{array}$} \\
\hline
\end{tabular}

\section{CONCLUSION}

Given the diverse advantages of FDI and potential research dearth on FDI - FD nexus in prior literature, especially in BRI cluster, this study examines the relationship between FDI and FD in 102 BRI member states across four regions from 1990 to 2017. Contemplating the existence of CSD, the second-generation panel unit root tests are applied. Westerlund (2007) cointegration is applied to demonstrating long-run dynamics. Furthermore, this study uses the D-H heterogeneous panel non-causality method to examine the dynamic causal links among the variables. We add value to the related literature using a relatively new index of FD and applied FGLS estimator coupled with the AMG which produced robust findings across the regions and income groups. 
Our long-run quantitative analysis indicates that FDI enhances FD in Asia, Europe, and Latin America. These economies have stronger financial structure to benefit significantly from FDI (Ang, 2009). However, FDI shows a negative effect in Africa. Therefore, policymakers should focus on improving the accessibility of monetary markets, refining financial regulations, and providing a competitive environment for foreign firms to join African countries. The $\mathrm{D}-\mathrm{H}$ causality test verifies the bidirectional causal relationships between FDI and FD in Asian and European countries; however, the causal connection is unidirectional in Latin America. The empirical analysis of the income-wise results shows that FDI has a significant favorable influence on FD. These results provide valuable implications, such as HI economies with a robust financial infrastructure receiving fewer FDI relative to LI and MI economies. This phenomenon may occur due to high labor, land, and capital costs in HI countries therefore international companies search for new investment opportunities. So they seek to spend less in HI countries (Liu et al., 2020).

Our findings have important theoretical and practical implications for policymakers, regulatory authorities, and other stakeholders. First, an increase in FDI net inflows would contribute to the expansion of economic activities and lead to an increase in funds available in the economy, which would boost financial intermediation through available financial markets or the banking system. Second, a relatively developed stock market increases the liquidity of listed companies and may eventually reduce capital cost, making the country more attractive for foreign investors (Desai et al., 2006; Henry, 2000). Further, policymakers in the BRI economies must concentrate on long-run measures to improve their financial systems. The negative influence of FD in African countries is essential for policymakers, focusing on the improvement of the financial system. As rising FDI inflows accelerate financial activities and result in higher available funds in the country. It also improves financial competitiveness through the existing financial markets (Otchere et al., 2016). Next, the results of a recent study showing that financial prosperity is a precondition for financial stability. A stable financial sector is crucial for overseas investors, which is an issue that should be addressed in the BRI countries (Gürler \& Kara, 2020).

It is an effort to provide a holistic view from 102 BRI countries that makes it difficult to design specific policies for each country. Future studies may examine the impact of FDI on FD on individual countries, through which country-specific policies can be formulated. Therefore, future research may be conducted by following different data sets and combinations of data from a wider period, or by using newly developed or non-linear estimation techniques, new control variables and or different measurements of financial development.

\section{Acknowledgement}

This work was supported by the National Natural Science Foundation of China (Grant No. 72073024). Dr. Abdul Majeed acknowledges financial support from ILMA University under the ILMA research grant program.

\section{Funding}

The project was funded under the program of the Minister of Science and Higher Education titled "Regional Initiative of Excellence" in 2019-2022, project number 018/RID/2018/19, the amount of funding PLN 10788 423,16 . 


\section{References}

1. Aibai, A., Huang, X., Luo, Y., \& Peng, Y. (2019). Foreign Direct Investment, Institutional Quality, and Financial Development along the Belt and Road: An Empirical Investigation. Emerging Markets Finance and Trade, 55 (14), 3275-3294. https://doi.org/10.1080/154049 6X.2018.1559139

2. Alfaro, L., Chanda, A., Kalemli-Ozcan, S., \& Sayek, S. (2010). Does foreign direct investment promote growth? Exploring the role of financial markets on linkages. Journal of Development Economics, 91 (2), 242-256. https://doi.org/10.1016/j.jdeveco.2009.09.004

3. Ang, J. B. (2009). Foreign direct investment and its impact on the Thai economy: The role of financial development. Journal of Economics and Finance, 33 (3), 316-323. https://doi.org/10.1007/ s12197-008-9042-6

4. Armand Fouejieu. (2017). Inflation targeting and financial stability in emerging markets. Economic Modelling, 60, 51-70. https://doi.org/10.1016/j.econmod.2016.08.020

5. Aziz, A., \& Makkawi, B. (2012). Relationship between Foreign Direct Investment and Country Population. International Journal of Business and Management, 7 (8), 457-467. https://doi. org/10.5539/ijbm.v7n8p63

6. Banerjee, A., Cockerell, L., \& Russell, B. (2001). An I (2) analysis of inflation and the markup. Journal of Applied Econometrics, 16, 221-240. https://doi.org/10.1002/jae.609

7. Bayar, Y., \& Gavriletea, M. D. (2018). Foreign direct investment inflows and financial development in Central and Eastern European Union countries: A panel cointegration and causality. International Journal of Financial Studies, 6 (2), 55. https://doi.org/10.3390/ijfs6020055

8. Bayar, Y., Remeikiene, R., Androniceanu, A., Gaspareniene, L., \& Jucevicius, R. (2020). The shadow economy, human development and foreign direct investment inflows. Journal of Competitiveness, 12 (1), 5-21. https://doi.org/10.7441/joc.2020.01.01

9. Becker, B. (2007). Geographical segmentation of US capital markets. Journal of Financial Economics, 85 (1), 151-178. https://doi.org/10.1016/j.jfineco.2006.07.001

10. Bhattacharya, M., Inekwe, J., \& Paramati, S. R. (2018). Remittances and financial development: empirical evidence from heterogeneous panel of countries. Applied Economics, 50, 4099-4112. https://doi.org/10.1080/00036846.2018.1441513

11. Borin, A., \& Mancini, M. (2016). Foreign direct investment and firm performance: an empirical analysis of Italian firms. Review of World Economics, 152, 705-732. https://doi. org/10.1007/s10290-016-0255-z

12. Buchanan, B. G., Le, Q. V., \& Rishi, M. (2012). Foreign direct investment and institutional quality: Some empirical evidence. International Review of Financial Analysis, 21, 81-89. https://doi. $\operatorname{org} / 10.1016 /$ j.irfa.2011.10.001

13. Butler, A. W., \& Cornaggia, J. (2011). Does access to external finance improve productivity? Evidence from a natural experiment. Journal of Financial Economics, 99 (1), 184-203. https://doi. org/10.1016/j.jfineco.2010.08.009 
14. Carkovic, M., \& Levine, R. E. (2005). Does Foreign Direct Investment Accelerate Economic Growth? Does Foreign Direct Investment Promote Development; Moran, T.H., Graham, E.M., Blomstrom, M., Eds.; Peterson Institute: Washington, DC, USA, 195. https://doi. org $/ 10.2139 /$ ssrn.314924

15. Desai, M. A., Foley, C. F., \& Hines, J. R. (2006). Capital controls, liberalizations, and foreign direct investment. Review of Financial Studies, 19 (4), 1433-1464. https://doi.org/10.1093/rfs/ hhj041

16. Dumitrescu, E. I., \& Hurlin, C. (2012). Testing for Granger non-causality in heterogeneous panels. Economic Modelling, 29 (4), 1450-1460. https://doi.org/10.1016/j.econmod.2012.02.014

17. Durusu-Ciftci, D., Ispir, M. S., \& Yetkiner, H. (2017). Financial development and economic growth: Some theory and more evidence. Journal of Policy Modeling, 39, 290-306. https://doi. org/10.1016/j.jpolmod.2016.08.001

18. Eberhardt, M. (2012). Estimating Panel Time-Series Models with Heterogeneous Slopes. The Stata Journal: Promoting Communications on Statistics and Stata, 12 (1), 61-71. https://doi. org/10.1177/1536867X1201200105

19. Enderwick, P. (2018). The economic growth and development effects of China's One Belt, One Road Initiative. Strategic Change, 27 (5), 447-454. https://doi.org/10.1002/jsc.2229

20. Fan, J.-J., Xu, R., Su, C. W., \& Shi, Q.-H. (2018). Demand-following or supply-leading? Trade openness and financial development in China. The Journal of International Trade \& Economic Development, 27, 314-332. https://doi.org/10.1080/09638199.2017.1390779

21. Frankopan, P. (2017). These Days, All Roads Lead To Beijing. New Perspectives Quarterly, 34 (4), 6-15. https://doi.org/10.1111/npqu.12102

22. Granger, C. W. J. (1969). Investigating Causal Relations by Econometric Models and Crossspectral Methods. Econometrica, 37 (3), 424. https://doi.org/10.2307/1912791

23. Gürler, M., \& Kara, F. (2020). The Relationship Between Foreign Direct Investment and Financial Development in OECD Countries. Handbook of Research on Decision-Making Techniques in Financial Marketing, 206-226. IGI Global. https://doi.org/10.4018/978-17998-2559-3.ch010

24. Hajilee, M., \& Nasser, O. M. A. (2015). The Relationship between Financial Market Development and Foreign Direct Investment in Latin American Countries. The Journal of Developing Areas, 49, 227-245. https://doi.org/10.1353/jda.2015.0043

25. Henri, N., Luc, N. N., Larissa, N., Njangang, H., Luc, N. N., \& Nawo, L. (2019). The Longrun and Short-run Effects of Foreign Direct Investment on Financial Development in African Countries. African Development Review, 31 (2), 216-229. https://doi.org/10.1111/1467-8268.12379

26. Henry, P. B. (2000). Do stock market liberalizations cause investment booms? Journal of Financial Economics, 58 (1), 301-334. https://doi.org/10.1016/s0304-405x(00)00073-8

27. Iamsiraroj, S. (2016). The foreign direct investment-economic growth nexus. International Review of Economics and Finance, 42, 116-133. https://doi.org/10.1016/j.iref.2015.10.044

28. Islam, M. A., Liu, H., Khan, M. A., Islam, M. T., \& Sultanuzzaman, M. R. (2021). Does foreign direct investment deepen the financial system in Southeast Asian economies? Journal of Multinational Financial Management. https://doi.org/10.1016/j.mulfin.2021.100682 
29. Kaidi, N., Mensi, S., \& Ben Amor, M. (2019). Financial Development, Institutional Quality and Poverty Reduction: Worldwide Evidence. In Social Indicators Research, 131-156. https:// doi.org/10.1007/s11205-018-1836-0

30. Katircioğlu, S., \& Zabolotnov, A. (2019). Role of financial development in economic globalization: evidence from global panel. Applied Economics Letters, 1-7. https://doi.org/10.108 0/13504851.2019.1616058

31. Kaulihowa, T., \& Adjasi, C. (2018). FDI and income inequality in Africa. Oxford Development Studies, 46, 250-265. https://doi.org/10.1080/13600818.2017.1381233

32. Khan, H., Khan, U., \& Khan, M. A. (2020). Causal nexus between economic complexity and FDI: Empirical evidence from time series analysis. The Chinese Economy, 5 3(5), 374 -394. https://doi.org/10.1080/10971475.2020.1730554

33. Khan, M. A., Khan, M. A., Abdulahi, M. E., Liaqat, I., \& Shah, S. S. H. (2019). Institutional quality and financial development: The United States perspective. Journal of Multinational Financial Management, 49, 67-80. https://doi.org/10.1016/j.mulfin.2019.01.001

34. Khan, M. A., Kong, D., Xiang, J., \& Zhang, J. (2019). Impact of Institutional Quality on Financial Development: Cross-Country Evidence based on Emerging and Growth-Leading Economies. Emerging Markets Finance and Trade, 55, 1-17. https://doi.org/10.1080/154049 6X.2019.1588725

35. Khan, M. A., Oláh, J., Máté, D., Popp, J., Sadaf, R., Khan, M. A., \& AbdulahiI, M. E. A. (2020). Do institutional quality, innovation and ICT technologies promote financial development. European Journal of International Management, 1 (1), 1. https://doi.org/10.1504/ ejim.2020.10025994

36. Kholdy, S., \& Sohrabian, A. (2008). Foreign direct investment, financial markets, and political corruption. Journal of Economic Studies, 35 (6), 486-500. https://doi. org/10.1108/01443580810916514

37. Kim, D. H., Lin, S. C., \& Suen, Y. B. (2010). Dynamic effects of trade openness on financial development. Economic Modelling, 27 (1), 254-261. https://doi.org/10.1016/j. econmod.2009.09.005

38. Kutan, A. M., Samargandi, N., \& Sohag, K. (2017). Does Institutional Quality Matter for Financial Development and Growth? Further Evidence from MENA Countries. Australian Economic Papers, 56 (3), 228-248. https://doi.org/10.1111/1467-8454.12097

39. La Porta, R., Lopez-de-Silanes, F., Shleifer, A., \& Vishny, R. W. (1998). Law and finance. Journal of Political Economy, 106 (6), 1113-1155. https://doi.org/10.1086/250042

40. Le, T. H., Kim, J., \& Lee, M. (2016). Institutional Quality, Trade Openness, and Financial Sector Development in Asia: An Empirical Investigation. Emerging Markets Finance and Trade, 52 (5), 1047-1059. https://doi.org/10.1080/1540496X.2015.1103138

41. Liu, H., Islam, M. A., Khan, M. A., Hossain, M. I., Pervaiz, K., Ismail, H. M., Pervaiz, K., Hossain, M. I., \& Pervaiz, K. (2020). Does financial deepening attract foreign direct investment? Fresh evidence from panel threshold analysis. Research in International Business and Finance, 53 (1), 101198. https://doi.org/10.1016/j.ribaf.2020.101198 
42. Mahmoodi, M., \& Mahmoodi, E. (2016). Foreign direct investment, exports and economic growth: evidence from two panels of developing countries. Economic Research-Ekonomska Istrą̌ivanja, 29 (1), 938-949. https://doi.org/10.1080/1331677X.2016.1164922

43. Otchere, I., Soumaré, I., \& Yourougou, P. (2016). FDI and Financial Market Development in Africa. World Economy, 39 (5), 651-678. https://doi.org/10.1111/twec.12277

44. Ozili, P. K. (2018). Impact of digital finance on financial inclusion and stability. Borsa Istanbul Review, 18 (4), 329-340. https://doi.org/10.1016/j.bir.2017.12.003

45. Parks, R. W. (1967). Efficient Estimation of a System of Regression Equations when Disturbances are Both Serially and Contemporaneously Correlated. Journal of the American Statistical Association, 62 (318), 500-509. https://doi.org/10.1080/01621459.1967.10482923

46. Pedroni, P. (2004). Panel cointegration: Asymptotic and finite sample properties of pooled time series tests with an application to the PPP hypothesis. Econometric Theory, 20 (3), 597-625. https://doi.org/10.1017/S0266466604203073

47. Peres, M., Ameer, W., \& Xu, H. (2018). The impact of institutional quality on foreign direct investment inflows: evidence for developed and developing countries. Economic ResearchEkonomska Istrazivanja, 31 (1), 626-644. https://doi.org/10.1080/1331677X.2018.1438906

48. Pesaran, M. H. (2004). General Diagnostic Tests for Cross Section Dependence in Panels. SSRN Electronic Journal, 1229 (August). https://doi.org/https://ssrn.com/abstract=572504

49. Pesaran, M. H. (2007). A simple panel unit root test in the presence of cross-section dependence. Journal of Applied Econometrics, 22, 265-312. https://doi.org/10.1002/jae.951

50. Pesaran, M. H., \& Yamagata, T. (2008). Testing slope homogeneity in large panels. Journal of Econometrics, 142 (1), 50-93. https://doi.org/10.1016/j.jeconom.2007.05.010

51. Reed, W. R., \& Ye, H. (2011). Which panel data estimator should I use? Applied Economics, 43, 985-1000. https://doi.org/10.1080/00036840802600087

52. Sahin, S., \& Ege, I. (2015). Financial Development and FDI in Greece and Neighbouring Countries: A Panel Data Analysis. Procedia Economics and Finance, 24, 583-588. https://doi. org/10.1016/s2212-5671(15)00640-1

53. Saidi, K. (2018). Foreign Direct Investment, Financial Development and Their Impact on the GDP Growth in Low-income Countries. International Economic Journal, 32 (3), 483-497. https:// doi.org/10.1080/10168737.2018.1529813

54. Sayılır, Ö., Doğan, M., \& Soud, N. S. (2018). Financial development and governance relationships. Applied Economics Letters, 25, 1466-1470. https://doi.org/10.1080/13504851.2018 .1430311

55. Sobiech, I. (2019). Remittances, finance and growth: Does financial development foster the impact of remittances on economic growth? World Development, 113, 44-59. https://doi. org/10.1016/j.worlddev.2018.08.016

56. Soumaré, I., \& Tchana, F. T. (2015). Causality and external validity: Causality between FDI and financial market development: Evidence from emerging markets. World Bank Economic Review, 29, 205-216. https://doi.org/10.1093/wber/lhv015 
57. Svirydzenka, K. (2016). Introducing a New Broad-based Index of Financial Development. IMF Working Papers. https://doi.org/10.5089/9781513583709.001

58. Tsagkanos, A., Siriopoulos, C., \& Vartholomatou, K. (2019). Foreign direct investment and stock market development: Evidence from a "new" emerging market. Journal of Economic Studies, 46, 55-70. https://doi.org/10.1108/JES-06-2017-0154

59. Westerlund, J. (2007). Testing for Error Correction in Panel Data. Oxford Bulletin of Economics and Statistics, 69 (6), 709-748. https://doi.org/10.1111/j.1468-0084.2007.00477.x

60. World Bank. (2020). Foreign direct investment, net inflows (BoP, current US\$) | Data. https://doi.org/https://data.worldbank.org/indicator/BX.KLT.DINV.CD.WD

61. Yeboua, K. (2019). Foreign direct investment, financial development and economic growth in Africa: evidence from threshold modeling. Transnational Corporations Review, 11, 187-189. https://doi.org/10.1080/19186444.2019.1640014

62. Zheng, J., \& Sheng, P. (2017). The impact of foreign direct investment (FDI) on the environment: market perspectives and evidence from China. Economies, 5, 8. https://doi. org/10.3390/economies5010008

\section{Contact information}

Dr. Abdul Majeed, Ph.D.

University of International Business and

Economics, Beijing 100029, China

School of International Trade and Economics

China

ILMA University, Karachi 72400, Pakistan

Department of Business Administration

Pakistan

E-mail:abdulmajeed192@hotmail.com;

DE201760051@uibe.edu.cn

ORCID: 0000-0001-5231-8756

Prof. Ping Jiang, Ph.D.

University of International Business and

Economics, Beijing 100029, China

School of International Trade and Economics

China

E-mail:ping.jiang@uibe.edu.cn

ORCID: 0000-0001-5932-2213

Mr. Mahmood Ahmad, Ph.D.

University of International Business and

Economics, Beijing 100029, China

School of International Trade and Economics

China

E-mail:mahmood_449@yahoo.com

ORCID: 0000-0002-9974-0150
Prof. Muhammad Asif Khan, Ph.D. (corresponding author)

University of Kotli, AJK, 11100, Pakistan

Faculty of Management Sciences

Department of Commerce

Pakistan

E-mail:khanasif82@uokajk.edu.pk.

ORCID: 0000-0002-3563-2951

Prof. Judit Olah, Ph.D.

WSB University, Faculty of Applied Sciences

Department of Management

41-300 Dabrowa Górnicza, Poland

Poland

E-mail:juditdrolah@gmail.com

ORCID: 0000-0003-2247-1711 